\title{
Professora do Ano 2021
}

\section{CITAÇÃo}

Professora do Ano 2021,

Rev. Ciência Elem., V9(04):061.

doi.org/10.24927/rce2021.061

\section{EDITOR}

João Nuno Tavares

Universidade do Porto

\section{PUBLICADO EM}

15 de dezembro de 2021

\section{COPYRIGHT}

(C) Casa das Ciências 2021.

Este artigo é de acesso livre, distribuído sob licença Creative Commons com a designação CC-BY-NC-SA 4.0, que permite a utilização e a partilha para fins não comerciais, desde que citado 0 autor e a fonte original do artigo.

\section{rce.casadasciencias.org}

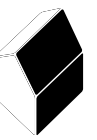

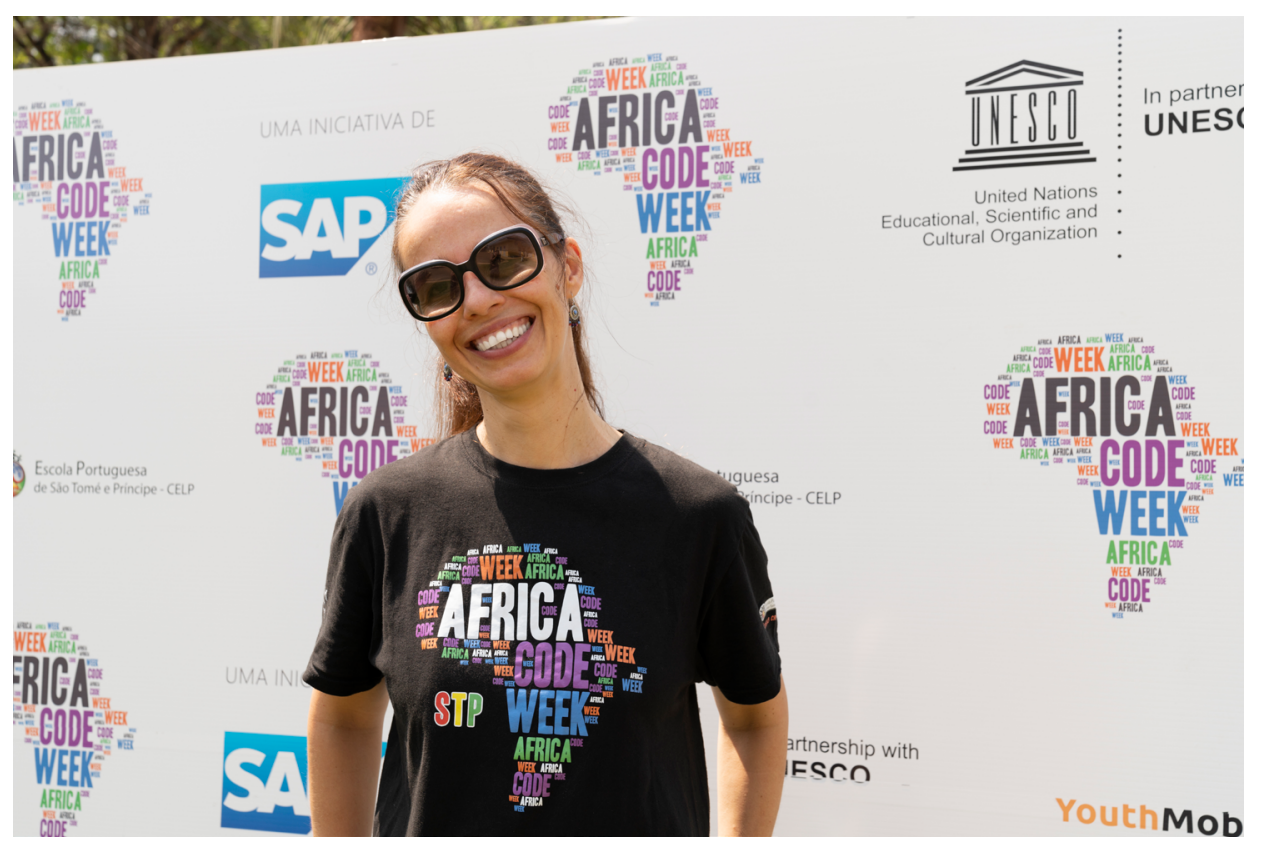

Carla Pereira Menino

A Carla Pereira Menino é professora de Tecnologias de Informação e Comunicação na Escola Portuguesa de São Tomé e Príncipe na sequência de um voluntariado realizado entre 2012 e 2013 como agente de Desenvolvimento, ao serviço da ONGD Leigos para o Desenvolvimento, tendo-lhe sido reconhecido o estatuto de agente da cooperação, por despacho do Senhor Secretário de Estado dos Negócios Estrangeiros e da Cooperação.

Licenciada em Informática de Gestão na Universidade Portucalense Infante D. Henrique em 1999, realizou entre 2003 e 2005 a Profissionalização em serviço na Escola Superior de Educação do Instituto Politécnico do Porto, tendo concluído posteriormente (em 2012) uma Pós-graduação, em Sistemas Gráficos e Multimédia no Instituto Superior de Engenharia do Porto.

Coordenadora do Clube de Robótica e Programação e responsável pelo projeto Africa Code Week (ACW) desenvolveu ao longo dos últimos anos uma significativa atividade no domínio do ensino da tecnologia e da sua envolvência na aprendizagem em geral, sendo responsável por projetos nesta área que envolveram desde a participação no First Global Challenge 2021 (uma competição internacional de robótica de estilo olímpico que decorre num país diferente em cada ano) até à configuração e organização de todas as disciplinas e turmas na plataforma Classroom de forma a facilitar as aulas online aquando da aclamação do estado de calamidade em S. Tomé e Príncipe. 
A sua passagem pelas várias escolas onde lecionou, com particular relevo para o Colégio dos Carvalhos onde foi aluna e docente, deixou significativas marcas como atestam os testemunhos que dela dão, aqueles com quem privou.

É uma mulher compreensiva, incentivadora, apaixonada pela docência. ... está sempre a querer fazer mais pelo agrupamento, a tentar implementar alguma ideia nova, ... tenta que todos os que a rodeiam consigam voar mais alto, na sua carreira profissional e na sua vida pessoal, incentivando-os a acreditarem nas suas potencialidades.

Maria José Ferreira Álvares, Professora e Delegada de Grupo da Secundária Manuel Laranjeira

A Carla não é só uma colega que estava sempre disponível para auxiliar nos contratempos da profissão e a encaminhar-me na resolução de situações mais adversas, mas também uma amiga que, nas horas de aflição, nos puxa para cima e nos mostra o caminho a seguir.

Susana Alves, Colega e amiga

É uma colega de trabalho que todos os anos se coloca a si desafios profissionais, que "inventa que fazer", que "põe a lenha toda na fogueira", e que facilmente convence e contagia quem a rodeia. Que humildemente reconhece que não sabe tudo, que tem tantas dúvidas como certezas, mas que vai aprender para saber fazer e ajudar. Que põe os alunos a brilhar! E uma pessoa deste calibre está predestinada a ter sucesso naquilo que faz e a ser reconhecida pelos pares. António Menino, Marido

Três palavras para descrever a Carla Menino: discrição; rigor; disponibilidade. Manuel Silva Pinto, Professor

"Professor do Ano" é a distinção atribuída anualmente pela Comissão Editorial da Casa das Ciências a um professor em reconhecimento do seu mérito como docente do ensino básico ou secundário e da sua disponibilidade de partilhar a sua experiência com os colegas. 